\title{
Effects of Abandoned Buildings on the Environment in Osogbo, Osun State, Nigeria
}

\author{
Ibrahim, R.B., Adedotun, S.B., Olawoyin, O.S. and Olawoyin, R.O.
}

\begin{abstract}
The study examined effects of abandoned buildings on the environment in five selected political wards in Osogbo, Osun State Nigeria. The study identified the types and causes of abandoned buildings in the study area. It assessed the incidence (nature) of abandoned buildings; conditions of environment in the abandoned buildings; and analyses spatial variations in the incidence of abandoned buildings in the study area. Data were obtained through physical enumeration of abandoned building. Also total of 202 structured questionnaires were randomly administered to residents in the study area. Descriptive statistics (mean) and inferential statistics (ANOVA) were used to analyse the data obtained. Findings reveals that death of owner (mean weighed value $=4.316)$, improper management (mean weighed value $=4.125)$, lack of fund (mean weighed value $=4.070)$, and dispute (mean weighed value $=3.935$ ) are the major causes of abandonment of buildings across the study area. Most of the incidence of abandoned buildings is residential with an average of 3 buildings in each area. This implies that an average of 3 residential buildings were abandoned in each area across the study area. Also the physical enumeration shows that 173, 113 and 111 are the total numbers of bungalow, storey building and Brazilian buildings abandoned respectively across the study area. Obscenity (mean weighed value $=4.094)$, crime (mean weighed value $=4.030)$, and pollution (mean weighed value $=3.949)$ are the major environmental effects of abandoned buildings across the study area. Results from Analysis of Variance (ANOVA) indicated that there is significant spatial variations in the incidence of abandoned buildings. The study concluded by recommending among others, that buildings prone to abandonment as a result of death of owner should be quickly assigned to the heirs. In the absence of heirs, the buildings should be in care of community leaders who will protect it from environmental consequences.
\end{abstract}

Keywords: Environment, Abandonment, Building, Effects, Development.

\section{Introduction}

Abandonment of building and its attendant environmental consequences is high the world over. [1], [2] and [3]. The number of abandoned buildings in Baltimore in 2001 is between 12,700 and 42, 480 [2]. Between 1996 and 2001 Detroit, Michigan demolished 18,200

\footnotetext{
Ibrahim, R.B., Adedotun, S.B. (Department of Urban and Regional Planning, Osun State University Osogbo, Nigeria)

Olawoyin, O.S. (Department of Civil Engineering, Osun State Polytechnic, Iree)

Olawoyin, R.O. (Department of Urban and Regional Planning, Osun State Polytechnic, Iree)

Corresponding author's email address: rafiu.ibrahim@uniosun.edu.ng
}

condemned buildings with an estimated 10,000 substandard structures still remaining. Razed buildings were estimated to be more than $20 \%$ of urban structures in Houston, Texas and more than $12 \%$ in Las Vegas, Nevada. [3]. Forth-Worth environmental management department in the United States has currently identified over 3,250 abandoned buildings in the city. An estimate of an average of $18 \%$ of urban structures is presented to be sitting unused based on a survey of 100 cities. If these situations hold for cities in the developed world of relative economic boom, the incidence of abandoned buildings in 
developing countries like Nigeria can only be better imagined [4].

[5] quoting [6] argued that Nigeria has become the "world's junk-yard of abandoned projects worth billions of naira and it is greatly unthinkable that Nigeria blessed with so great potentials in the construction industry can experience such magnitude of project abandonment". There are about 4000 uncompleted or abandoned projects belonging to the Federal Government of Nigeria with an estimated cost of over N 300 billion which will take 30 years to complete at the present execution capacity of government. Also according to him this issue of abandonment being left without adequate attention for too long is now having negative a multiplier effect on the environment.

Abandoned buildings can be identified by buildings outgrown with grasses or bushes [7]. The existence of abandoned building developments is another phenomenon in the country's housing industry. It has become a serious problem and is considered as one of the national problems, since it involves a high number of housing projects and estate managers. Indeed, building abandonment has caused a waste of money for reviving processes and the waste of resources: land and human resources. For the purpose of this study, it is therefore important to understand the matter of abandoned building in Osogbo empirically.

It is useful to offer a precise definition of the concept of building abandonment for this study. This is because the definition and the concept of building abandonment in Osogbo might be different from those of other countries. For example, in the United Kingdom, building abandonment refers to the existence of housing projects which have been completed, and is related to low demand for housing that is usually more to do with second- hand stock [8]. In other words, the term 'building abandonment' in the UK refers to empty property. In the case of Nigeria, the term 'abandoned building projects' refers to "incomplete housing projects approved by the Housing Authority and abandoned by the building developers [9].

According to [9], building abandonment jeopardizes public health. It frustrates neighbours and causes contaminations. Abandoned lands are unsafe spaces with real imagined or perceived environmental contamination [10]. Abandonment causes the inability to provide necessary information needed to keep up and maintain the neighbourhood by the local government agents responsible for providing such services [11]. Abandoned structures are targets for arson [12]. This is etched in the high statistics of fire incidences in abandoned buildings [12], [13] and [14]. Abandonment of building is thus worth to be discouraged and at best converted the existing ones for useful gains in our community. This study therefore appraises the effects of abandoned buildings on the totality of the environment in Osogbo, Nigeria.

\section{Materials and Methods}

\section{A. The Study Area}

Osogbo lies between Latitudes $7^{\circ} 42^{\prime} 10^{\prime \prime}$ and $7^{\circ} 51^{\prime} 10^{\prime \prime}$ North and Longitudes $4^{\circ} 28^{\prime} 43^{\prime \prime}$ and $4^{\circ} 40^{\prime} 12^{\prime \prime}$ East as shown in figure 1. Osogbo is the state capital city of Osun State. Osogbo city seats the Headquarters of both Osogbo Local Government Council (situated at OkeBaale Area of the city) and Olorunda Local Government Council (situated at Igbonna Area of the city). It is some 88 kilometers by road Northeast of Ibadan. It is also 100 kilometers by road South of Ilorin and 115 kilometers Northwest of Akure. Osogbo 


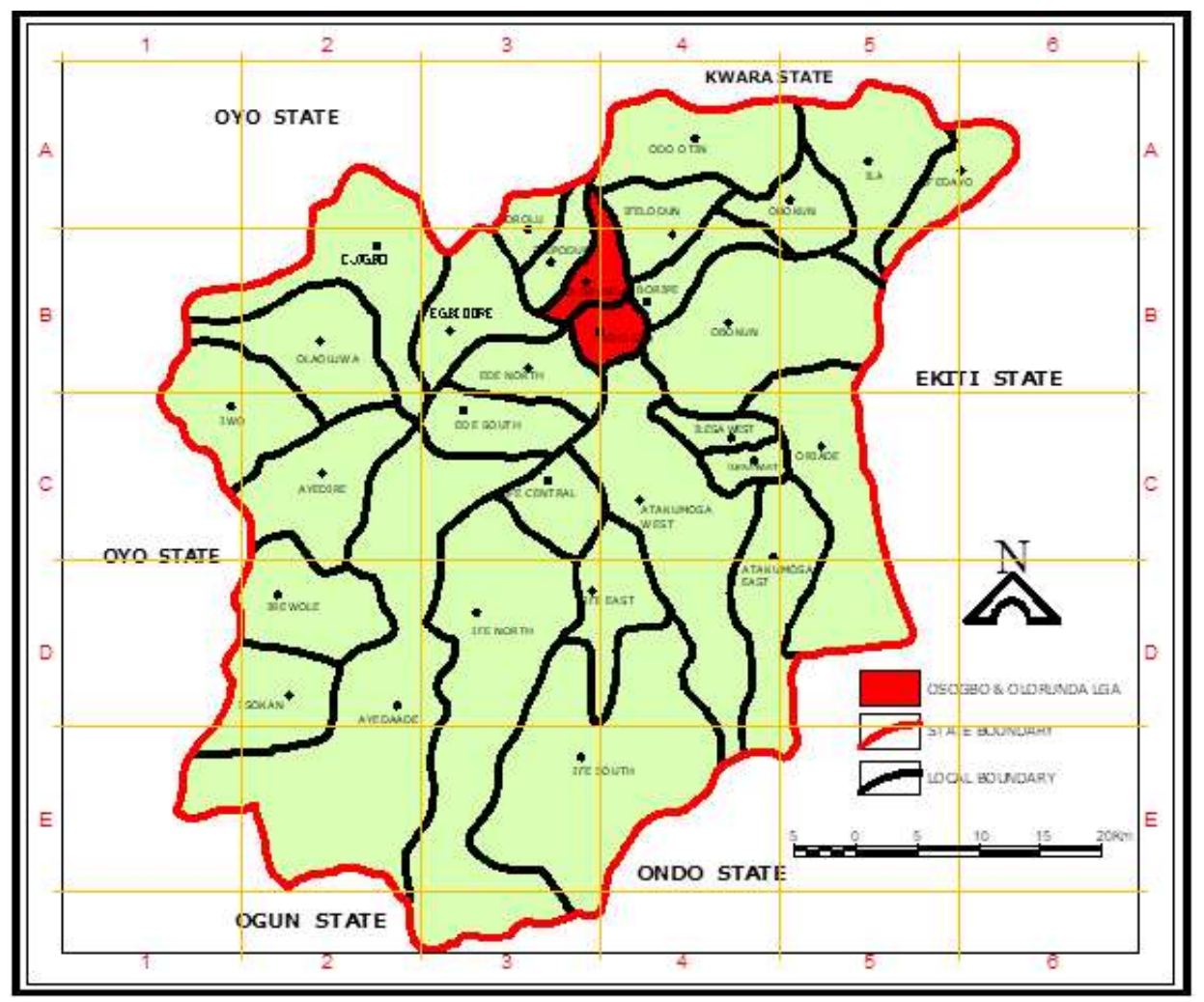

Figure 1: Map of Osogbo in the context of Osun State.

Source: Ministry of Land, Housing and Physical Planning Osun State 2008.

Table1: Types of abandoned buildings in Osogbo.

\begin{tabular}{|c|c|c|c|c|c|c|c|c|c|c|}
\hline \multirow[t]{2}{*}{$\mathrm{S} / \mathrm{N}$} & \multirow[t]{2}{*}{ Variables } & \multicolumn{5}{|c|}{ Ranking } & \multirow[t]{2}{*}{ F(NR) } & \multirow[t]{2}{*}{ SWV } & \multirow[t]{2}{*}{ MWV } & \multirow[t]{2}{*}{ Rank } \\
\hline & & 5 & 4 & 3 & 2 & 1 & & & & \\
\hline 1 & Residential Building & 675 & 236 & 9 & 6 & 2 & 202 & 928 & 4.594 & 1 \\
\hline 2 & Commercial Building & 245 & 356 & 123 & 36 & 6 & 199 & 766 & 3.849 & 2 \\
\hline 3 & Institutional Building & 195 & 148 & 189 & 54 & 36 & 202 & 622 & 3.079 & 3 \\
\hline 4 & Public Building & 60 & 212 & 144 & 94 & 41 & 201 & 551 & 2.741 & 4 \\
\hline 5 & Industrial Building & 95 & 128 & 144 & 90 & 58 & 202 & 515 & 2.549 & 5 \\
\hline 6 & Recreational Building & 35 & 96 & 123 & 102 & 78 & 202 & 434 & 2.148 & 6 \\
\hline & Total & & & & & & & & 18.96 & \\
\hline
\end{tabular}

Mean of $\sum M W V / n=18.96 / 6=3.16$ Source: Author's Fieldwork, 2018

Table 2: Causes of abandoned buildings in Osogbo.

\begin{tabular}{|c|c|c|c|c|c|c|c|c|c|c|}
\hline \multirow[t]{2}{*}{$\mathbf{S} / \mathbf{N}$} & \multirow[t]{2}{*}{ Variables } & \multicolumn{5}{|c|}{ Ranking } & \multirow[t]{2}{*}{ F(NR) } & \multirow[t]{2}{*}{ SWV } & \multirow[t]{2}{*}{ MWV } & \multirow[t]{2}{*}{ Rank } \\
\hline & & 5 & 4 & 3 & 2 & 1 & & & & \\
\hline 1 & Death of owner & 540 & 252 & 69 & 6 & 5 & 202 & 872 & 4.316 & 1 \\
\hline 2 & Natural disaster & 200 & 304 & 93 & 24 & 42 & 201 & 663 & 3.298 & 7 \\
\hline 3 & Community interference & 265 & 140 & 210 & 54 & 16 & 201 & 685 & 3.407 & 6 \\
\hline 4 & Dispute & 285 & 380 & 96 & 26 & 4 & 201 & 791 & 3.935 & 4 \\
\hline 5 & Lack of fund & 495 & 188 & 69 & 56 & 2 & 199 & 810 & 4.070 & 3 \\
\hline 6 & Improper management & 345 & 224 & 224 & 20 & 8 & 199 & 821 & 4.125 & 2 \\
\hline 7 & Inflation & 310 & 216 & 147 & 52 & 9 & 200 & 734 & 3.670 & 5 \\
\hline 8 & Faulty design & 65 & 224 & 234 & 78 & 15 & 201 & 616 & 3.064 & 8 \\
\hline 9 & Government policy & 70 & 96 & 198 & 104 & 45 & 201 & 513 & 2.552 & 10 \\
\hline \multirow[t]{2}{*}{10} & Wrong estimate & 46 & 220 & 177 & 90 & 34 & 202 & 567 & 2.806 & 9 \\
\hline & Total & & & & & & & & 35.243 & \\
\hline
\end{tabular}

Mean of $\Gamma \mathrm{MWV} / \mathrm{n}=35.243 / 10=3.524$

Source: Author's Fieldwork, 2018 
Egbedore and Iragbiji and is easily accessible from any part of the state because of its central nature. It is about $48 \mathrm{~km}$ from Ife, $32 \mathrm{~km}$ from Ilesa, $46 \mathrm{~km}$ from Iwo, $48 \mathrm{~km}$ from Ikire and $46 \mathrm{~km}$ from Ila-Orangun. According to the 2006 census exercise, Osogbo had a population of 156,694 .

\section{B. Method of Data Collection and Analysis} The study used both primary and secondary sources of data. The secondary data were through literature search on the subject matter. For primary sources, a reconnaissance survey of the study area was carried out to determine the number of abandoned buildings. Five political wards were purposively sampled out of total 23 political wards in the city of Osogbo. Moreover, 202 randomly selected residents in 5 political wards (Owode, Powerline, OkeBaale, Oke Ayepe and Ayetoro) were interviewed using structured questionnaire to collect data on the types and causes of abandoned buildings as well as conditions of environment in the vicinity of abandoned buildings.

The data gathered were analyzed using descriptive and inferential statistics. For descriptive statistics, mean, frequencies and percentages, were used to examine types and causes of abandoned buildings, incidence of abandonment; and environmental effects of the abandoned buildings. The Likert scale was used for the analyses of data collected. This was done by attaching values of weight to different degree of responses as shown: Very high (5), High (4), Fairly high (3), Low (2), Very low (1). The SWV (Summary Weight Value) was obtained by summing up the product of the total numbers of responses to each variables and the weight attached to each rating i.e. $(\mathrm{a} \times 5)+(\mathrm{b} \times 4)+(\mathrm{c} \times 3)+(\mathrm{d} \times 2)+(\mathrm{e} \times$
1). The mean used in the course of computation was also obtained by summing up the MWV and dividing it by the total number of variables. For inferential statistics, Analysis of Variance (ANOVA) was used to analyze spatial variations in the incidence of abandoned buildings in the study area.

\section{Research Findings}

\section{A. Types of abandoned buildings in Osogbo.}

In this sub-section, attempt is made to examine the types of abandoned buildings in five selected political wards in Osogbo. This is with a view to understanding respondents' opinion about the various types of abandoned buildings in the study area. It could be noted that people living around the abandoned buildings are in a better position to describe the types of building being abandoned in their area. This is because of the interaction they had with the construction workers at one point or the other. Table 1 shows the types of abandoned buildings in the study area. It was observed in Table 1 that residential buildings have the highest mean weighted value of 4.594. This implies that Residential buildings are mostly the type of building abandoned in the study area. This situation is followed in decreasing order by Commercial buildings having a mean weighted value of 3.849, Institutional buildings (3.079); Public buildings (2.741); Industrial buildings (2.549) and Recreational buildings (2.148). Specifically, it could be observed however, that most of the responses were above average in their opinion about types of abandoned buildings in the study area, except Recreational building which is lesser than average. Nevertheless, the overall mean value of responses of types of abandoned buildings in the study area, as obtained from the users is 
Table3: Average incidence of abandoned buildings in Osogbo.

\begin{tabular}{|c|c|c|c|c|c|c|c|c|c|c|c|}
\hline $\mathrm{S} / \mathrm{N}$ & Areas & Bungalow & $\begin{array}{c}\text { Storey } \\
\text { building }\end{array}$ & Duplex & Brazilian & Church & Mosque & School & $\begin{array}{l}\text { Health } \\
\text { center }\end{array}$ & Factory & Average \\
\hline 1 & Oke-Baale & 2.23 & 1.42 & 1.46 & 1.38 & 1.35 & 0.73 & 0.92 & 0.42 & 0.69 & 1.17 \\
\hline 2 & Power line & 4.08 & 3.14 & 2.22 & 2.92 & 0.53 & 0.61 & 0.83 & 0.22 & 0.31 & 1.65 \\
\hline 3 & Ayetoro & 2.23 & 2.48 & 1.58 & 2.11 & 0.86 & 0.55 & 0.65 & 0.25 & 0.37 & 1.23 \\
\hline 4 & Oke-Ayepe & 3.05 & 2.50 & 1.94 & 2.77 & 0.78 & 0.44 & 0.86 & 0.31 & 0.56 & 1.46 \\
\hline \multirow[t]{2}{*}{5} & Owode & 3.68 & 3.55 & 2.76 & 3.55 & 0.68 & 0.61 & 0.84 & 0.39 & 0.42 & 1.83 \\
\hline & Average & 2.99 & 2.67 & 1.97 & 2.55 & 0.82 & 0.58 & 0.79 & 0.30 & 0.44 & \\
\hline
\end{tabular}

Source: Author's Fieldwork, 2018

Table 4: Physical enumeration of abandoned buildings in Osogbo.

\begin{tabular}{clcccccc}
\hline S/N & Building Type & Oke-Baale & Power-Line & Ayetoro & Oke-Ayepe & Owode & Total \\
\hline 1 & Bungalow & 49 & 16 & 23 & 27 & 58 & $\mathbf{1 7 3}$ \\
2 & Storey building & 29 & 9 & 20 & 15 & 40 & $\mathbf{1 1 3}$ \\
3 & Duplex & 17 & 6 & 4 & 9 & 26 & $\mathbf{6 2}$ \\
4 & Brazilian & 43 & 11 & 9 & 25 & 23 & $\mathbf{1 1 1}$ \\
5 & Church & 3 & 2 & 3 & 0 & 3 & $\mathbf{1 1}$ \\
6 & Mosque & 1 & 2 & 1 & 0 & 2 & $\mathbf{6}$ \\
7 & School & 3 & 0 & 0 & 3 & 2 & 8 \\
8 & Health center & 0 & 0 & 0 & 0 & 0 & $\mathbf{0}$ \\
9 & Factory & 3 & 2 & 0 & 0 & 3 & 8 \\
& Total & $\mathbf{1 4 8}$ & $\mathbf{4 8}$ & $\mathbf{6 0}$ & $\mathbf{7 9}$ & $\mathbf{1 5 7}$ & $\mathbf{4 8 9}$ \\
\hline
\end{tabular}

Source: Author's Fieldwork, 2018

3.16. This implies that mean responses of the people were above average indicating that buildings are abandoned in the study area.

\section{B. Causes of Abandoned Buildings in Osogbo.}

This sub-section focuses on identifying the causes of abandoned buildings in five selected political wards in Osogbo. This is with a view to understanding respondent's opinion about the various causes of abandoned buildings in the study area. The variables of the causes include: death of owner, natural disaster, community interference, dispute, lack of fund, improper management, inflation, faulty design, government policy, and wrong estimate.

Causes of abandoned buildings is also one of the issues examined in this study as contained in Table 2. Death of owner is observed to be the highest cause of building abandonment in the study area with the mean weighted value of 4.316. With a mean weighted value of 2.225 'Government policy' emerged as the lowest cause of building abandonment in the study area. Also, the overall mean value of responses of causes of abandoned buildings in the study area, as obtained from the respondents is 3.524. This implies that the mean responses of people were above average indicating that those are the major causes of abandoned buildings in the study area.

\section{Incidence (Nature) of Abandoned Buildings in Osogbo.}

This sub-section presents the view of respondents concerning the incidence of abandoned buildings in five selected political wards in Osogbo. This is with a view to understanding respondent's opinion about the various incidences of abandoned buildings in the study area. The variables of the incidences are; Bungalow, Story building, Duplex, 
Table5: Effects of abandoned buildings on Peoples' Environment in Osogbo.

\begin{tabular}{|c|c|c|c|c|c|c|c|c|c|c|}
\hline \multirow[t]{2}{*}{$\mathbf{S} / \mathbf{N}$} & \multirow[t]{2}{*}{ Variables } & \multicolumn{5}{|c|}{ Ranking } & \multirow[t]{2}{*}{ F(NR) } & \multirow[t]{2}{*}{ SWV } & \multirow[t]{2}{*}{ MWV } & \multirow[t]{2}{*}{ Rank } \\
\hline & & 5 & 4 & 3 & 2 & 1 & & & & \\
\hline 1 & Indecency & 355 & 372 & 87 & 8 & 5 & 202 & 827 & 4.094 & 1 \\
\hline 2 & Pollution & 310 & 300 & 156 & 8 & 4 & 197 & 778 & 3.949 & 3 \\
\hline 3 & Crime & 450 & 204 & 102 & 38 & 4 & 198 & 798 & 4.030 & 2 \\
\hline 4 & Health problem & 165 & 300 & 162 & 58 & 8 & 199 & 693 & 3.482 & 8 \\
\hline 5 & Financial loss & 285 & 252 & 153 & 46 & 6 & 200 & 742 & 3.710 & 6 \\
\hline 6 & Declined property value & 355 & 220 & 138 & 46 & 7 & 202 & 766 & 3.792 & 4 \\
\hline 7 & Resources wastage & 325 & 224 & 168 & 38 & 5 & 201 & 760 & 3.781 & 5 \\
\hline 8 & Dangerous reptiles & 155 & 240 & 240 & 68 & 13 & 198 & 716 & 3.616 & 7 \\
\hline 9 & Accident and vagrancy & 115 & 188 & 195 & 104 & 15 & 202 & 617 & 3.054 & 9 \\
\hline 10 & Development control & 90 & 196 & 234 & 72 & 20 & 201 & 612 & 3.044 & 10 \\
\hline 11 & $\begin{array}{l}\text { Unemployment } \\
\text { Total }\end{array}$ & 115 & 160 & 168 & 102 & 32 & 202 & 577 & $\begin{array}{l}2.856 \\
39.408\end{array}$ & 11 \\
\hline
\end{tabular}

Mean of $\sum M W V / n=39.408 / 11=3.582$

Source: Author's Fieldwork, 2018

Table 6: Analysis of Variance (ANOVA) of spatial variations in the incidence of abandoned buildings in the study area.

\begin{tabular}{|c|c|c|c|c|c|c|c|c|}
\hline $\mathbf{S} / \mathbf{N}$ & \multicolumn{2}{|c|}{ Building type } & \multirow{2}{*}{$\begin{array}{c}\begin{array}{c}\text { Sum of } \\
\text { Squares }\end{array} \\
113.949\end{array}$} & \multirow{2}{*}{\begin{tabular}{|c|} 
Df \\
4
\end{tabular}} & \multirow{2}{*}{$\begin{array}{c}\begin{array}{c}\text { Mean } \\
\text { Square }\end{array} \\
28.487\end{array}$} & \multirow{2}{*}{$\begin{array}{c}\mathbf{F} \\
4.327\end{array}$} & \multirow{2}{*}{$\begin{array}{c}\text { Sig. } \\
0.002\end{array}$} & \multirow{2}{*}{$\begin{array}{c}\text { Remark } \\
\text { Significant }\end{array}$} \\
\hline 1 & & Between Groups & & & & & & \\
\hline & Bungalow & Within Groups & 1297.006 & 197 & 6.584 & & & \\
\hline & & Total & 1410.955 & 201 & & & & \\
\hline \multirow[t]{3}{*}{2} & & Between Groups & 81.405 & 4 & 20.351 & 2.273 & 0.063 & Not \\
\hline & Storey building & Within Groups & 1755.262 & 196 & 8.955 & & & Significant \\
\hline & & Total & 1836.667 & 200 & & & & \\
\hline \multirow[t]{3}{*}{3} & & Between Groups & 41.587 & 4 & 10.397 & 1.682 & 0.156 & Not \\
\hline & Duplex & Within Groups & 1205.168 & 195 & 6.180 & & & Significant \\
\hline & & Total & 1246.755 & 199 & & & & \\
\hline \multirow[t]{3}{*}{4} & & Between Groups & 92.784 & 4 & 23.196 & 2.439 & 0.048 & Significant \\
\hline & Brazilian & Within Groups & 1854.716 & 195 & 9.511 & & & \\
\hline & & Total & 1947.500 & 199 & & & & \\
\hline \multirow[t]{3}{*}{5} & & Between Groups & 11.146 & 4 & 2.786 & 2.193 & 0.071 & Not \\
\hline & Church & Within Groups & 249.043 & 196 & 1.271 & & & Significant \\
\hline & & Total & 260.189 & 200 & & & & \\
\hline \multirow[t]{3}{*}{6} & & Between Groups & 1.354 & 4 & 0.339 & 0.432 & 0.786 & Not \\
\hline & Mosque & Within Groups & 153.700 & 196 & 0.784 & & & Significant \\
\hline & & Total & 155.055 & 200 & & & & \\
\hline \multirow[t]{3}{*}{7} & & Between Groups & 2.134 & 4 & 0.533 & 0.411 & 0.801 & Not \\
\hline & School & Within Groups & 253.046 & 195 & 1.298 & & & Significant \\
\hline & & Total & 255.180 & 199 & & & & \\
\hline \multirow[t]{3}{*}{8} & & Between Groups & 1.140 & 4 & 0.285 & 0.670 & 0.613 & Not \\
\hline & Health center & Within Groups & 83.348 & 196 & 0.425 & & & Significant \\
\hline & & Total & 84.488 & 200 & & & & \\
\hline \multirow[t]{3}{*}{9} & & Between Groups & 3.124 & 4 & 0.781 & 1.337 & 0.257 & Not \\
\hline & Factory & Within Groups & 114.468 & 196 & 0.584 & & & Significant \\
\hline & & Total & 117.592 & 200 & & & & \\
\hline
\end{tabular}

Source: Author's Fieldwork, 2018

Brazilian, Church, Mosque, School, Health center, and Factory.

Table 3 shows the average incidence of abandoned buildings in the study area. According to the table, there is an average of 2.99 abandoned Bungalow building, 2.67
Storey building, 1.97 Duplex, 2.55 Brazilian, 0.82 Church, 0.58 Mosque, 0.79 School. 0.30 Health center and 0.44 Factory across the study area. This implies that the bungalow type of building has the highest average incidence of abandonment in the study area. This was also 
as a result the less population of high rise buildings in the study area.

Table 4, shows the physical enumeration of abandoned buildings in the study area with a total of 489. Out of this, Owode has the highest number of abandoned buildings (157), followed by Oke-Baale (148), Oke-Ayepe (79), Ayetoro (60) and Power-line (48) respectively. Also in the enumeration of building types, Bungalow type of building appeared to be the highest with 173 counts, next is Storey building (113), Brazilian (111), Duplex (62), Church (11), School and Factory with (8), Mosque (6) while Health center $(0)$ respectively across the study area. This implies that there is a huge amount of abandoned Bungalow across the study area in which most of them are concentrated in Owode.

\section{Conditions of Environment in the Abandoned Buildings in Osogbo.}

In this sub-section of the study, the analysis of respondents' opinion on the effects of abandoned buildings on peoples' environment in Osogbo is presented. The term environment is used to describe the aggregate of all the external forces, influences and conditions, which affect the life, nature, behaviour and the growth, development and maturity of living organisms. As a matter of fact, the environment conceptually, means the surrounding external conditions influencing development or growth of people, animal or plants; living or working conditions etc. In this study however, environment is used in the light of above definition. This implies that variables used to measure environment has to do with forces surrounding and influencing life of human being. Some of the variables used to examine this include; indecency, pollution, crime, health problem, financial loss, declined property value, resources wastage, dangerous reptiles, accident and vagrancy, development control problem, and unemployment.

In Table 5 the environmental impact of abandoned buildings in the study area was situated. However, 'obscenity' is the highest environmental effect of building abandonment in the study area with the mean weighted value of 4.094. With a mean weighted value of 2.856 'Unemployment' emerged as the lowest environmental effect of building abandonment in the study area. Also, the overall mean value of responses of causes of abandoned buildings in the study area, as obtained from the respondents is 3.582. This implies that the mean responses of people were above average indicating the presence of environmental threat as a result of abandoned buildings.

\section{E. Spatial Variations in the Incidence of Abandoned Buildings}

The hypothesis was stated that there are no spatial variations in the incidence of abandoned buildings in the study area. The result is contained in Table 6 .

Table 6, shows the spatial variations in the incidence of abandoned buildings in the study area. According to the table, it is observed that Bungalow $(\mathrm{F}=4.327, \mathrm{p}=0.002)$ and Brazilian $(\mathrm{F}=2.439, \mathrm{p}=0.048)$ types of abandoned buildings were found to have statistical significance at $\mathrm{P}<0.05$. This implies that there is a statistical significant spatial variation in the incidence of abandoned buildings in these two types of building. For other building types, it was observed that there is no statistical significant spatial variations in the incidence of abandoned buildings in other types of building. This implies that the situation of abandoned buildings concerning other types of building 
remain the same across the 5 selected political wards in the study area.

\section{Conclusion and Policy Issues}

This study has assessed the situation of the environment of abandoned buildings in five selected political wards in Osogbo. Environmental effect of abandoned buildings in the study area is not favorable. It was observed that there are substantial occurrences of abandoned buildings of different types across the study area with residential type of buildings being the most dominant type of abandoned buildings and the environmental effect of this abandonment cannot be waved off as it appears to be so alarming across the study area. The following recommendations are advanced towards amelioration of the environmental effect of abandoned buildings in the study area:

i. Buildings prone to abandonment as a result of death of owner should be in care of community leaders so as to avoid abandonment after which it can be reclaimed by whoever is in line to be the owner with maintenance fee.

ii. The reduction in prices of building material so as to enhance quick completion of a started project.

iii. The eradication of low quality building materials by the government so as to lengthen the durability of buildings in the study area.

iv. The government can also implement a policy to reduce the duration of abandoning an ongoing building construction by application of fines.

v. The government can also help in the renovation of existing buildings which happens to be old to avoid abandonment. vi. Before construction on buildings, EIA must be presented so as to know the future environmental effect of such building.

\section{References:}

[1] Setterfield Mark (1997)"Abandoned Buildings: Models for Legislative and Enforcement Reform.” http://www.trincoll.edu/depts/tcn/research reports/resrch23.htm

[2] Cohen James R. (2001)"Abandoned Housing: Exploring Lessons from Baltimore". Journal of Housing Policy Debate Vol. 12 Issue 3 Fannie Mae Foundation.

[3] Mallach, A. (2004): Abandoned Properties: Effective Strategies to Reclaim Community Assets.Journal of Housing Factsand findings Vol 6 Issue 2. National Centre for Policy Analysis (2004), Cities Basin considering the risk of vacant building, Washington DC. Pp.205 - 208.

[4] Ayodele, E.O. and Alabi, O. M. (2011), Abandonment of Construction Projects in Nigeria: Causes and Effects; Journal of Emerging Trends in Economics and Management Sciences (JETEMS), Vol. 2, Iss. 2, pp. 142-145.

[5] Akindele O.A. (2013): Environmental Effects of Abandoned Properties in Ogbomoso and Osogbo, Nigeria. Ethiopian Journal of Environmental Studies and Management Vol. 6 2013. Management, Vol. 20, pp. 593-599.

[6] Aibinu, A. A. and Jagboro, G. O. (2002): The Effects of Construction Delays on Project Delivery in Nigeria Construction Industry; International Journal of Project Management Vol. 20, pp593-599.

[7] Adedibu, A. A. and Akindele, O. A. (2007): "The Significance of Landed Property Abandonment in Osogbo: A Planner's perspective". Journal of Nigerian Institute of Town Planners Vol XX No 1, pp. 125 - 127.

[8] Aluko O.O. (2008): Construction project abandonment in Nigeria: A Threat to National Economy; Knowledge Review, Vol. 16, Iss. 3, pp. $18-23$. 
[9] Akindele O. A. and Adedibu A. A. (2012): Abandoned Buildings Cooperative Landlords: An all Profitable Panacea to Landed Property Abandonment. Journal of Environmental Science and Resources Management. Pp. 1-12.

[10] UN-HABITAT (2003). The challenge of Slum: Global Report on Human Settlements. London: Earthscan Publications.

[11] Sternlieb G., Burshell R., Hughes J., and James F. (1994) "Housing Abandonment in the Urban Core". Journal of the American Institute of Planner 40: 321 - 332 .

[12] James Q. Wilson and George L. Kelling (1982): 'Broken Windows: The police and neighborhood safety'. Retrieved 2007/09/03.

[13] Akindoyemi, A. (1989): The Management of Abandoned Project, Journal of Nigerian Institute of Building, Vol. 1, Iss. 2, pp. 27.

[14] Abdul Kadir, M.R.; Lee, W.P.; Jaafar, M.S.; Sapuan, S. M. and Ali, A.A.A. (2005): "Factors Affecting Construction Labour Productivity for Malaysian Residential Projects", Structural Survey, Vol. 23 Iss: 1, pp.42- 54. 